\title{
DECISÕES ESTRUTURANTES NA JURISDIÇÃO CONSTITUCIONAL BRASILEIRA: CRITÉRIOS PROCESSUAIS DA TUTELA JURISDICIONAL DE DIREITOS PRESTACIONAIS
}

\author{
MELINA GIRARDI FACHIN ${ }^{\dagger}$ \\ CAIO CESAR BuENO SCHINEMANN ${ }^{\dagger}$
}

RESUMO: Este estudo se insere na temática acerca da tutela jurisdicional de direitos prestacionais. Trata-se de objeto já amplamente estudado pela doutrina desde a promulgação da Constituição de 1988. Identificou-se que o esforço doutrinário sobre o tema se deu especialmente a partir da proposição de critérios materiais da tutela jurisdicional de direitos prestacionais, por meio da qual se pretendeu estabelecer sobre quais direitos e em que intensidade poderia recair a atuação do Poder Judiciário. Compreende-se que estes critérios materiais são insuficientes para uma efetiva racionalização da atividade jurisdicional neste campo, propondo-se o desvio analítico dos critérios materiais para os critérios de ordem processual. Estes critérios processuais são identificados na adoção de decisões estruturantes pela jurisdição constitucional brasileira como instrumento de tutela jurisdicional de direitos prestacionais. São estruturantes as decisões por meio das quais se busca a reestruturação de determinada organização social ou política pública, com o objetivo de concretizar direitos ou interesses socialmente relevantes. Expõe-se a origem de provimentos de natureza estruturante na jurisdição constitucional norte-americana e sua ressignificação pelo constitucionalismo social. Por fim, são apresentados os parâmetros, possibilidades e fundamentos legais das decisões estruturantes, a fim de tornar possível sua operacionalização na jurisdição constitucional brasileira.

Palavras-Chave: Jurisdição constitucional; Direitos prestacionais; Constitucionalismo social; Processo constitucional comparado.

\footnotetext{
+ Doutora em Direito Constitucional, com ênfase em direitos humanos, e Mestre em Filosofia do Direito (PUC-SP). Visiting researcher da Harvard Law School (Estados Unidos da América). Professora da Faculdade de Direito (UFPR).

++ Bacharel em Direito pela Universidade Federal do Paraná.
} 


\begin{abstract}
This research discusses the judicial protection of welfare rights. This theme has been largely studied by constitutional doctrine since the promulgation of the Brazilian Constitution of 1988. It was identified that the doctrinal effort on this subject was especially the proposition of material standards on the judicial protection of these rights benefits, which means the discussion on what rights should be protected and its intensity. However, these material standards are insufficient for an effective rationalization of the jurisdictional activity in this field, and that's why this study proposes the adoption of procedural standards along the well know material standards. These procedural standards are identified in the conception of structural injunctions. These are the judicial decisions that intends to restructure social organizations or public policies, aiming to accomplish socially relevant rights and interests. This study discusses the origin of structural injunctions North American constitutional jurisdiction and its resignification by the social constitutionalism. Finally, it exposes the parameters, possibilities and legal bases of the structural injunctions in Brazilian constitutional jurisdiction.
\end{abstract}

KEYWORDS: Judicial review; Social and economic rights; Social constitutionalism; Comparative judicial review. 


\section{DECISÕES ESTRUTURANTES NA JURISDIÇÃO CONSTITUCIONAL BRASILEIRA}

\section{INTRODUÇÃO}

A tutela jurisdicional de direitos humanos ${ }^{1}$, especialmente os prestacionais, ${ }^{2}$ é certamente um dos assuntos mais estudados - se não o mais - pela doutrina constitucional brasileira a partir da Constituição de 1988. Entretanto, contraditoriamente, verifica-se uma cegueira deliberada do Poder Judiciário na apreensão e aplicação das críticas doutrinárias à prática jurisdicional.

O exemplo mais ilustrativo é a judicialização do direito à saúde. Ainda que, ao menos a partir da primeira metade da década de 2000, a doutrina tenha passado a sistematicamente se posicionar de modo crítico em relação aos efeitos da judicialização individual do direito à saúde, ${ }^{3} \mathrm{o}$ impacto orçamentário decorrente de decisões desta natureza aumenta a cada ano. ${ }^{4}$ No mesmo sentido, o progressivo aumento dessa judicialização indica que as condenações sofridas pelo Estado não necessariamente influenciam a formulação das políticas públicas alheias aos provimentos jurisdicionais condenatórios.

Há uma evidente lacuna na prática constitucional brasileira: a jurisprudência pouco dialoga com a doutrina no quanto aos parâmetros,

\footnotetext{
${ }^{1}$ Ainda que este trabalho se refira, em maior medida, à ordem constitucional interna, optou-se pela terminologia "direitos humanos" por se considerar insustentável uma distinção entre direitos fundamentais, humanos e da personalidade de acordo com o campo no qual a discussão se insere - interno, internacional ou privado. Estes devem ser vistos de modo associado, pois consubstanciam um todo holístico e integral em torno dos valores de dignidade que gravitam. Cf. FACHIN, Melina Girardi; GONÇALVES, Marcos Alberto Rocha. De fora, de cima e de baixa - todos os sentidos da dignidade no discurso dos direitos. Revista brasileira de direitos e garantias fundamentais. Curitiba, v. 2, n. 2, p. 78 -94, jul./dez. 2016, p. 90.

2 'Direitos prestacionais' são direitos humanos que estabelecem pretensões a uma prestação em face do Estado, podendo decorrer de tanto de direitos civis e políticos, quanto dos direitos sociais e econômicos. Parte da doutrina compreende a expressão 'direitos prestacionais' como sinônimo de 'direitos sociais e econômicos', razão pela qual parte da literatura utilizada é referente aos direitos sociais, sem prejuízo de considerar que todos os direitos humanos (sociais ou não) são dotados de viés prestacional e, portanto, podem ser objeto do que aqui se discute.

${ }^{3}$ Para uma sistematização destas posições, SARMENTO, Daniel; SOUZA NETO, Claudio Pereira, (orgs.). Direitos sociais: fundamentos, judicialização e direitos sociais em espécie. Rio de Janeiro: Lumen Juris, 2008.

${ }^{4}$ CNJ. Relatório anual do Poder Judiciário - 2016, p. 104.
} 
possibilidades, critérios e potencialidades da tutela jurisdicional de direitos prestacionais, bem como o Executivo não dialoga com a jurisprudência na formulação de políticas públicas.

Esta lacuna traz ínsita a si duas principais consequências: em primeiro, justifica a retomada do estudo da tutela jurisdicional de direitos prestacionais, a despeito da vasta produção já existente sobre o tema; e, em segundo, demonstra que as balizas doutrinárias erigidas até o momento, além de revisitadas, devem ser questionadas.

Este estudo, portanto, é inserido nos debates a respeito da tutela jurisdicional de direitos fundamentais, mas pretende revisitar e questionar as concepções doutrinárias dominantes sobre o tema. Identificou-se que o direito constitucional brasileiro tentou racionalizar a tutela jurisdicional de direitos prestacionais por meio de critérios de ordem material, ou seja, quais direitos devem ser tutelados e em que intensidade, e não avançou sobre os critérios de ordem processual

Critérios processuais da tutela jurisdicional de direitos prestacionais se relacionam a (i) um modelo de processo que torne o Judiciário ambiente mais propício para discutir direitos cuja tutela implica impacto sobre o Erário; e (ii) os meios de tornar a implementação dessa decisão (ou, em termos processuais, o cumprimento de sentença) mais adequado do ponto de visto orçamentário. Este artigo, nestes termos, propõe um desvio analítico, para que a tutela jurisdicional de direitos prestacionais seja concebida não apenas por meio de critérios materiais, mas também pelos critérios processuais elencados.

O estudo do modelo de processo e o modo de implementação da decisão na noção de decisão estruturante. O conceito de decisão estruturante aqui adotado é o desenvolvido pela doutrina dos Estados Unidos a partir da década de 1960, especificamente no proposto por Owen Fiss e Abram Chayes. São estruturantes as decisões judiciais nas quais, a partir de um litígio que transcende o interesse individual e privado e, portanto, é de interesse público, ${ }^{5}$ se busca a reestruturação de determinada organização social ou política pública, com o objetivo de concretizar direitos fundamentais ou interesses socialmente relevantes. ${ }^{6}$

Pretende-se verificar a viabilidade de adoção dos provimentos estruturais no direito brasileiro, especialmente em relação aos direitos prestacionais. Como hipótese provisória, entende-se que segmentar as discussões relativas à tutela jurisdicional de direitos prestacionais aos

${ }^{5}$ CHAYES, Abram. The role of the judge in public law litigation. Harvard Law Review, vol. 89, n. 7, 1976.

${ }^{6}$ FISS, Owen. The forms of justice. Harvard Law Review, vol. 93, n. 1, 1979. 


\section{DECISÕES ESTRUTURANTES NA JURISDIÇÃO CONSTITUCIONAL BRASILEIRA}

provimentos de natureza estruturante significa inverter a lógica vigente na jurisprudência brasileira: este tipo de tutela deve, como regra, partir de provimentos coletivos e de interesse públicos (portanto, estruturantes), em contraposição a uma tutela individual e privada, que deve ser cada vez mais excepcional.

\section{A TUTELA JURISDICIONAL DE DIREITOS PRESTACIONAIS A PARTIR DE SEUS CRITÉRIOS MATERIAIS}

A tutela jurisdicional de direitos prestacionais, no modelo vigente na jurisprudência brasileira, se dá, em regra, individualmente e é submetida a instrumentos executivos típicos. Ainda que as milhares de decisões em processos individuais, somadas, impliquem um amplo impacto na alocação dos recursos do Estado, ${ }^{7}$ seu cumprimento é naturalizado porque a concretização do provimento judicial, nestes casos, utiliza os instrumentos executivos já consolidados por uma lógica individual e bipolarizada ${ }^{8}$ de processo.

Novamente, o exemplo mais relevante no caso brasileiro especialmente do ponto de vista quantitativo - é a judicialização da saúde. Dados de julho de 2017 demonstram que, dentre 118,6 mil decisões que condenaram o Estado ao fornecimento de medicamentos, apenas 474 foram descumpridas, ${ }^{9}$ o que infere no baixíssimo índice de $0,4 \%$ de descumprimento.

Aplica-se à adjudicação em direitos prestacionais em face do Estado, de forma pouco criteriosa, as mesmas premissas processuais que são aplicadas ao litígio privado. O bloqueio judicial de bens, medida coercitiva típica no âmbito privado, por exemplo, teve sua utilização corroborada pelo Superior Tribunal de Justiça para casos em que o Estado

\footnotetext{
7 BARROSO, Luís Roberto. Da falta de efetividade à judicialização excessiva: direito à saúde, fornecimento gratuito de medicamentos e parâmetros para a atuação judicial. In: SARMENTO, Daniel; SOUZA NETO, Claudio Pereira, (orgs.). Direitos Sociais: Fundamentos, Judicialização e Direitos Sociais em Espécie. Rio de Janeiro: Lumen Juris, 2008, p. 875-904.

${ }^{8} \mathrm{O}$ termo é de Abram Chayes, que o utiliza justamente para distinguir as demandas comuns dos litígios de interesse público. CHAYES, Abram. The role of the judge in public law litigation. Harvard Law Review, vol. 89, n. 7, 1976.

9 FOLHA DE SÃO PAULO. Doentes graves ganham na Justiça, mas remédios caros travam no SUS. 16.07.2017.
} 
não cumpriu decisão que ordena fornecimento de medicamento a determinado indivíduo. ${ }^{10}$

Uma jurisprudência pouco criteriosa na concessão de provimentos prestacionais, que não considera o impacto que as várias concessões da mesma natureza irão causar, não passou incólume ao crivo doutrinário. A tentativa de racionalizar a atividade jurisdicional no âmbito dos direitos prestacionais se deu, na doutrina brasileira, especialmente a partir da proposição de critérios materiais para a adjudicação destes direitos. Buscou-se estabelecer quais direitos deveriam ser diretamente garantidos pelo Poder Judiciário e em que intensidade. A racionalização de uma limitação material da tutela jurisdicional de direitos prestacionais, ao mesmo tempo, impediria uma desmedida intervenção da jurisdição sobre as decisões alocativas de recurso, mas também impediria a manutenção de uma omissão reiterada e violadora de direitos humanos pelo Estado.

Há ampla produção na doutrina nacional acerca de parâmetros de ordem material como critério para a atuação jurisdicional, especificamente naquilo que se denominou 'mínimo existencial' ${ }^{11}$ Uma das proposições mais conhecidas neste âmbito é a desenvolvida por Ana Paula de Barcellos.

O conteúdo do mínimo existencial, de acordo com Ana Paula de Barcellos, é construído a partir de um rol objetivo e preferencial estabelecido pela própria Constituição. Integrariam o mínimo existencial o direito à educação, à saúde básica, a assistência aos desamparados e o acesso à justiça ${ }^{12}$ porque sua densificação é normativamente prevista no texto constitucional.

Ainda que seja de extrema pertinência a tentativa de dar parâmetros objetivos à tutela jurisdicional de direitos prestacionais por meio destes critérios de ordem material, é problemático conceber o mínimo existencial a partir de um rol taxativo de seu conteúdo. Isto porque a taxatividade deste conteúdo esvazia uma das mais importantes funções do mínimo existencial, a de "lastrear demandas que, conquanto ligadas à

${ }^{10} \mathrm{O}$ caso foi decidido em recurso especial afetado pelo regime dos recursos repetitivos e, sendo assim, é vinculante aos graus ordinários de jurisdição. STJ. Recurso especial 1.069.810/RS. Rel. Min. Napoleão Nunes Maia Filho, 1ª Seção, julgado em 23.10.2013.

11 Para a revisão da literatura sobre o tema na doutrina brasileira, SARMENTO, Daniel.

Dignidade da pessoa humana: conteúdo, trajetórias e metodologia. $2^{a}$ ed., Belo Horizonte: Fórum, 2016.

12 BARCELLOS, Ana Paula de. A eficácia jurídica dos princípios constitucionais: o princípio da dignidade da pessoa humana. 3. ed. Rio de Janeiro: Renovar, 2011. 


\section{DECISÕES ESTRUTURANTES NA JURISDIÇÃO CONSTITUCIONAL BRASILEIRA}

dignidade humana, não estão inseridas em qualquer outro direito fundamental expressamente positivado". ${ }^{13}$

Além disso, ainda que, novamente, seja meritória a tentativa de Ana Paula de Barcellos estabelecer uma categoria passível de universalização, considerando sua natureza objetiva, o conteúdo do mínimo existencial é variável. É possível que haja a variação do conteúdo do mínimo existencial entre diferentes indivíduos. Esta análise perpassa pela a análise das necessidades de cada pessoa concreta, considerando, que esta categoria "não remete ao universalismo abstrato (...) cego às diferenças e especificidades de cada sujeito". ${ }^{14}$

Isto não significa negar uma base de universalidade do mínimo existencial. Entretanto, a pretensão de universalidade a partir da constatação de que sujeitos diferentes possuem demandas distintas faz com que se construa uma noção de mínimo existencial cujo conteúdo seja “universalizável no sentido de que as suas prestações são extensíveis a todos os que se encontrarem na mesma situação"..$^{15}$

Por fim, Ana Paula de Barcellos, justamente por dar ao mínimo existencial um conteúdo fixo, entende que este estabelece o teto máximo da possibilidade de atuação da jurisdição na tutela de direitos prestacionais. Este entendimento, entretanto, encontra dois principais óbices.

O primeiro é a positivação de direitos para além do mínimo existencial na própria Constituição, inferindo em prestações as quais não possuem vínculo inexorável com as necessidades básicas do cidadão, mas, dada sua previsão expressa, a proteção judicial desses direitos deve se dar de forma ampla. ${ }^{16}$

O segundo óbice é a máxima efetividade inerente aos direitos fundamentais, somada à inafastabilidade da jurisdição. O critério hermenêutico da máxima efetividade preconiza que "deve preferir-se a

13 SARMENTO, Daniel. Dignidade da pessoa humana: conteúdo, trajetórias e metodologia. $2^{a}$ ed., Belo Horizonte: Fórum, 2016, p. 227.

14 SARMENTO, Daniel. Dignidade da pessoa humana: conteúdo, trajetórias e metodologia. $2^{a}$ ed., Belo Horizonte: Fórum, 2016, p. 215.

15 SARMENTO, Daniel. Dignidade da pessoa humana: conteúdo, trajetórias e metodologia. $2^{a}$ ed., Belo Horizonte: Fórum, 2016, p. 216.

${ }_{16}$ Por exemplo, a participação nos lucros ou resultados (XI) e o aviso prévio proporcional ao tempo de serviço (XXI). 
interpretação que reconheça maior eficácia aos direitos fundamentais". ${ }^{17}$ Isto impede que a atuação do Poder Judiciário na tutela jurisdicional de direitos, incluindo os direitos prestacionais, seja abstratamente limitado a um rol mínimo. A possibilidade ou não de oferecer tutela mais ampla que o mínimo deve ser aferida no caso concreto.

A partir das críticas formuladas à concepção corrente dos critérios materiais de atuação da jurisdição na tutela de direitos prestacionais, compreende-se que (i) não é possível definir, a priori, qual é o conteúdo material deste mínimo existencial; e (ii) ainda que fosse, esta categorização seria insuficiente, pois não é possível restringir, de antemão, a tutela jurisdicional ao mínimo existencial. A conclusão preliminar a que se chega é, paradoxalmente, pouco conclusiva: ao mesmo tempo em que se concebe os direitos prestacionais enquanto objeto possível de tutela jurisdicional, compreende-se que esta tutela se dá, por vezes, de modo inadequado e seletivo. Portanto, os critérios de ordem material não foram suficientes para, por si só, dar parâmetros satisfatórios à tutela jurisdicional dos direitos prestacionais.

O que se passa a investigar é a forma pela qual é possível conciliar a potencialidade emancipatória presente nas normas enunciadoras de direitos prestacionais e a busca por uma tutela jurisdicional adequada. Este estudo apresenta como proposta a adoção de decisões estruturantes. Estas consubstanciam uma série de parâmetros processuais que devem conformar a atuação jurisdicional na tutela de direitos prestacionais, conformando-as a um processo necessariamente coletivo (e não individual) e ligada a um interesse intrinsicamente público (e não privado).

O desafio que se coloca, além de desenhar um processo próprio para este tipo de discussão, é a fase de implementação de decisão dessa natureza. Litígios individuais e privados tem seu processo de tomada de decisão e implementação já naturalizado. Por outro lado, as decisões que são alheias esta perspectiva privada não tem à sua disposição os instrumentos tradicionais de implementação das decisões judiciais. ${ }^{18}$

17 CANOTILHO, J. J. Gomes. Direito constitucional e teoria da constituição. 7. ed. Coimbra: Almedina, 2003, p. 1224.

18 Cf. RODRÍGUEZ-GARAVITO, César; RODRÍGUEZ-FRANCO, Diana. Cortes y cambio social: cómo la Corte Constitucional transformó el desplazamiento forzado en Colombia. Bogotá: Centro de Estudios de Derecho, Justicia y Sociedad, 2010. No caso brasileiro, a melhor ilustração do que se sustenta são os litígios envolvendo saneamento básico: BARCELLOS, Ana Paula de. Sanitation rights, public law litigation 


\section{DECISÕES ESTRUTURANTES NA JURISDIÇÃO CONSTITUCIONAL BRASILEIRA}

O deslocamento que se propõe, na tentativa de alterar este cenário, perpassa pela justificação da conveniência e operacionalização de decisões estruturantes na jurisdição constitucional brasileira. É o que se passa a intentar.

\section{DE BROWN AO ESTADO DE COISAS INCONSTITUCIONAL: AS DIFERENTES CONFORMAÇÕES}

A origem da concepção de decisões estruturantes é intrinsicamente ligada ao estudo da implementação das decisões da jurisdição constitucional. Owen Fiss caracteriza a adjudicação estruturante a partir da decisão da Suprema Corte dos Estados Unidos que determinou o fim da segregação racial nas escolas. ${ }^{19} \mathrm{~A}$ implementação da decisão da Corte, neste caso, necessariamente perpassaria pela reforma estrutural de instituições de grande porte, ${ }^{20}$ como se verificou no primeiro e mais conhecido exemplo de provimento estruturante: Brown vs. Board of Education of Topeka.

Linda Brown (1943-2018) era uma criança em idade escolar, habitante de Topeka, cidade do Estado do Kansas, nos Estados Unidos. Em 1951, ao tentar matricular a filha em escola próxima à sua residência, seu pai, Oliver Brown, teve o pedido rejeitado. Linda e Oliver eram negros, e a escola em questão aceitava apenas crianças brancas.

O segregacionismo, do ponto de vista legal, era característica presente, em maior ou menor grau, em toda a sociedade norte-americana por meio das chamadas leis de Jim Crow, promulgadas após a Guerra Civil, em especial nos estados do sul. ${ }^{21}$ A Suprema Corte chancelou a constitucionalidade de leis desta natureza em 1896, com o julgamento de Plessy vs. Ferguson. ${ }^{22}$

and inequality: a case study from Brazil. Harvard Health and Human Rights Journal, n. 2, vol. 16, 2014.

19 US SUPREME COURT. Brown vs. Board of Education of Topeka, 347 U.S. 483 (1954)

${ }^{20}$ A primeira decisão neste caso foi proferida em 1954. Um ano depois, o caso voltou à Suprema Corte para que fossem discutidos os mecanismos de implementação da decisão anterior. US SUPREME COURT. Brown vs. Board of Education of Topeka. 349 U.S. 294 (1955).

${ }^{21}$ FISS, Owen. Um novo processo civil: estudos norte-americanos sobre jurisdição, constituição e sociedade. São Paulo: Revista dos Tribunais, 2004, p. 47.

${ }^{22}$ US SUPREME COURT. Plessy v. Ferguson, 163 U.S. 537 (1896). 
Em Plessy, a Suprema Corte analisou a constitucionalidade de lei do Estado da Louisiana que estabelecia a divisão de vagões de trens entre pessoas brancas e negras. $\mathrm{O}$ entendimento estabelecido foi o de que esta divisão não violava a cláusula proteção igualitária prevista na $14^{\mathrm{a}}$ Emenda da Constituição dos Estados Unidos. ${ }^{23}$ Foi este o precedente judicial que legitimou a doutrina separate but equal.

A sociedade norte-americana possuía divisões que iam muito além dos vagões de trem da Louisiana. Escolas, hospitais, transporte público, praias, piscinas, hotéis e, enfim, praticamente todos os espaços de convivência social possuíam algum grau de segregação entre brancos e negros na maior parte do país. ${ }^{24}$

No mesmo ano de 1951, Oliver Brown ajuizou ação contra a Secretaria de Educação (Board of Education) da cidade Topeka, objetivando a admissão de sua filha na escola que anteriormente a recusou. Era o início do mais importante caso da Suprema Corte no século XX. ${ }^{25}$

O caso foi pautado para decisão da Suprema Corte em 1954, admitido com outros treze casos nos quais também se discutia a constitucionalidade de segregação em escolas. ${ }^{26}$ A questão de direito a ser enfrentada pela Corte era se "a segregação das escolas públicas em base em critérios de raça viola a cláusula de proteção igualitária da $14^{a}$ Emenda". ${ }^{27}$

O questionamento que circundava Brown, portanto, era idêntico ao anteriormente respondido em Plessy vs. Ferguson: o sentido da norma inscrita na $14^{\mathrm{a}}$ Emenda. Estabelecer entendimento diverso do anteriormente decidido significaria superar um precedente amplamente aceito e institucionalizado na sociedade norte-americana por meios das leis e práticas segregacionistas.

Foi o que a Corte fez. De forma unânime, decidiu-se pela inconstitucionalidade da doutrina separate but equal, reconhecendo que

${ }^{23} \mathbf{1 4}^{\mathbf{a}}$ Emenda. Seção I. Todas as pessoas nascidas ou naturalizadas nos Estados Unidos e sujeitas a sua jurisdição são cidadãos dos Estados Unidos e do Estado onde tiver residência, Nenhum Estado poderá (...) negar a qualquer pessoa sob sua jurisdição a igual proteção das leis.

24 SCHLANGER, Margo. Beyond the hero judge: institutional reform litigation as litigation. Michigan Law Review, v. 97, n. 6, 1999, p. 2000-2003.

${ }^{25}$ FISS, Owen. Models of adjudication. Caderno Direito GV, v. 1, n. 8, 2005, p. 06.

${ }^{26}$ ARENHART, Sérgio Cruz. Decisões estruturais no direito processual civil brasileiro. Revista de Processo, v. 225, 2013, p. 391.

27 ESTADOS UNIDOS DA AMÉRICA. US Supreme Court. Brown v. Board of Education of Topeka, 347 U.S. 483 (1954). 


\section{DECISÕES ESTRUTURANTES NA JURISDIÇÃO CONSTITUCIONAL BRASILEIRA}

divisão de escolas a partir de critérios étnico-raciais carecia de substrato constitucional.

Em que pese a decisão, vinculada ao caso concreto, tenha se adstrito à segregação em escolas, era bastante claro que as políticas segregacionistas presentes nas mais variadas esferas da sociedade, anteriormente legitimadas por pelo que se decidiu em Plessy, deveria ser superada.

Com a decisão, Brown e os casos com ele admitidos foram devolvidos para as Cortes de Justiça Federal locais a fim de dar cumprimento às ordens antissegregacionistas. Como já era esperado pela própria Suprema Corte, a implementação da decisão encontrou ampla resistência social, ${ }^{28}$ de modo que, no ano seguinte, o caso voltou à Suprema Corte sob a alcunha de Brown II. ${ }^{29}$

Se em Brown I a problemática girava ao redor de uma questão jurídica - o significado da cláusula de igualdade inscrita na $14^{\mathrm{a}}$ emenda -, o discutido em Brown II assumiu a complexidade que o contexto social no qual a decisão foi prolatada lhe conferia. ${ }^{30} \mathrm{~A}$ Corte passou a discutir não mais a declaração de direito, mas o modo pelo qual a decisão de Brown I seria implementada. ${ }^{31}$

É neste momento que Owen Fiss identifica "o nascimento de uma nova forma de adjudicação, ${ }^{32}$ o que se chamou de reformas estruturais" ${ }^{33}$ Brown II inaugurou a noção segundo a qual as Cortes deveriam buscar

\footnotetext{
${ }^{28}$ FISS, Owen. The forms of justice. Harvard Law Review, vol. 93, n. 1, 1979, p. 05.

${ }^{29}$ ESTADOS UNIDOS DA AMÉRICA. US Supreme Court. Brown v. Board of Education of Topeka, 349 U.S. 294 (1955).

30 VIOLIN, Jordão. Holt v. Sarver e a reforma do sistema prisional no Arkansas. In: ARENHART, Sérgio; JOBIM, Marco Félix (org.). Processos estruturais. Salvador: JusPodivm, 2017, p. 303.

${ }^{31}$ FISS, Owen. The forms of justice. Harvard Law Review, vol. 93, n. 1, 1979, p. 07.

32 Adjudication, no sentido utilizado por Owen Fiss, é termo genérico que se liga à atividade desempenhada pelo Poder Judiciário quando este dá resposta acerca de conflitos sociais. No direito brasileiro, a tradução literal, adjudicação, possui sentido parecido, mas é usualmente ligado à noção específica de atribuir algo a alguém, como, por exemplo, a adjudicação do objeto da licitação ou a adjudicação da posse. Não obstante, de ora em diante, o termo adjudicação será utilizado enquanto sinônimo de adjudication, ou seja, em uma perspectiva mais ampla e genérica.

${ }_{33}$ FISS, Owen. Two models of adjudication. In: DIDIER JR., Fredie; JORDÃO, Eduardo Ferreira. Teoria geral do processo. Salvador: JusPodivm, 2007, p. 790-791.
} 
"uma reconstrução da realidade social, tendo de superar a mais intensa resistência, intervir e reestruturar organizações de grande porte" ${ }^{34}$

Esta nova forma de compreender a adjudicação somente foi possível em razão da compreensão de que processo e substância se ligam de maneira inexorável. As inovações procedimentais empreendidas em Brown se justificaram porque a Corte estabeleceu um compromisso primordial com a igualdade racial, estabelecendo um distanciamento dos mecanismos tradicionais de processo e o tornando permeável às reformas estruturais. ${ }^{35}$ Brown permitiu, nos termos de Owen Fiss, a abertura para "novas maneiras de observar a relação entre direitos e medidas judiciais". ${ }^{36}$

À origem das decisões estruturantes na jurisdição constitucional norte-americana com o combate à segregação em escolas somou-se, enquanto exemplo proeminente de provimentos desta natureza, as discussões que envolviam o sistema prisional dos Estados norteamericanos.

A partir de Holt vs. Sarver, ${ }^{37}$ - caso em que, pela primeira vez, "todo o sistema prisional de um Estado teve sua constitucionalidade impugnada judicialmente" 38 -, a prison law litigation se popularizou no país. Em 1993, 40 Estados norte-americanos enfrentavam ações similares. ${ }^{39}$

Nos casos de prison law litigation, a racionalidade das decisões foi a mesma de Brown II: era necessária uma reforma que operasse de modo estrutural nas organizações sociais, de modo prospectivo, e não apenas reparatório, para que os valores constitucionais fossem concretizados.

Em ambos os casos exemplificados - eliminação da segregação racial e intervenção no sistema prisional -, a reestruturação das organizações sociais proposta perpassa por prestações do Estado, como a adequação da qualidade de ensino ofertada com o fim da segregação nas escolas e a construção de novas unidades prisionais. Entretanto, no âmbito da

\footnotetext{
${ }^{34}$ FISS, Owen. The forms of justice. Harvard Law Review, vol. 93, n. 1, 1979, p. 14.

${ }_{35}$ FISS, Owen. The forms of justice. Harvard Law Review, vol. 93, n. 1, 1979, p. 17.

${ }^{36}$ FISS, Owen. The forms of justice. Harvard Law Review, vol. 93, n. 1, 1979, p. 15.

${ }^{37}$ US. DISTRICT COURT FOR THE EASTERN DISTRICT OF ARKANSAS. 309 F. Supp. 362 (E.D. Ark. 1970) February 18, 1970.

38 VIOLIN, Jordão. Holt v . Sarver e a reforma do sistema prisional no Arkansas. In: ARENHART, Sérgio; JOBIM, Marco Félix (org.). Processos estruturais. Salvador: JusPodivm, 2017, p. 307-308.

39 VIOLIN, Jordão. Holt v. Sarver e a reforma do sistema prisional no Arkansas. In: ARENHART, Sérgio; JOBIM, Marco Félix (org.). Processos estruturais. Salvador: JusPodivm, 2017, p. 307.
} 


\section{DECISÕES ESTRUTURANTES NA JURISDIÇÃO CONSTITUCIONAL BRASILEIRA}

jurisdição constitucional norte-americana, a fundamentação destas decisões não parte da questão econômico-social evidentemente ínsita a estes, mas foca em direitos de matriz liberal, como a igualdade e a integridade física.

A sistemática constitucional norte-americana não permitiria, por exemplo, discussões que diretamente incidissem na violação ao direito à educação de Linda Brown. Operou-se a resolução de seu caso tão somente a partir dos parâmetros jurídicos decorrentes do direito à igualdade.

Esta conformação se altera com a recepção dos processos estruturantes pelos constitucionalismos emergentes. Nestes contextos, as decisões estruturantes continuam a significar, tal qual na jurisdição constitucional norte-americana, mecanismos jurisdicionais de reestruturação de determinados arranjos da sociedade, ${ }^{40}$ mas os contornos assumidos por este instrumento se ligam ao viés social e economicamente emancipatório destas constituições ${ }^{41}$ sobretudo diante a reiterada omissão estatal na proteção e promoção de direitos humanos.

As noções de litígio de interesse público e provimentos jurisdicionais estruturantes, portanto, foram ressignificadas em sua recepção pelos constitucionalismos do Sul global. Com a constitucionalização dos direitos socioeconômicos, os valores constitucionais a serem tutelados por meio de provimentos estruturantes assumem o caráter emancipatório próprio destes direitos. A ameaça imposta a tais valores, por sua vez, passa a decorrer não somente de uma ação estatal, mas, na maior parte das vezes, de uma omissão reiterada.

A noção originária de decisão estruturante, oriunda da jurisdição constitucional norte-americana, não foi rompida pelos

\footnotetext{
${ }^{40}$ A noção apresentada por Cézar Rodriguez Garavito a partir do contexto colombiano, por exemplo, é bastante similar àquela proposta por Owen Fiss e Abram Chayes: tratam-se de decisões de repercussão supraindividual (pois afetam um grande número de pessoas), as quais requerem a reestruturação de determinada organização social (a partir de remédios estruturais) a fim de proteger e promover direitos fundamentais. RODRÍGUEZ-GARAVITO, César. Beyond the courtroom: the impact of judicial activism on socioeconomic rights in Latin America. Texas Law Review, vol. 89, 2011.

${ }^{41} \mathrm{O}$ viés emancipatório ao qual se faz referência diz respeito ao catálogo de direitos previstos nestas constituições, mas não diz respeito a seu arranjo institucional propriamente dito. Acerca da coexistência de direitos de cunho social, afirmados no século $\mathrm{XX}$, com a organização de poderes de matriz liberal, forjada no século XIX, especificamente no caso do constitucionalismo latino-americano, GARGARELLA, Roberto. La sala de máquinas de la Constitución. Buenos Aires: Katz, 2014.
} 
constitucionalismos emergentes. Entretanto, a esta concepção se somaram os novos significados próprios do constitucionalismo social.

Verifica-se a uma tendência "na América Latina e outras regiões do Sul global de a jurisdição constitucional atuar estruturalmente nos casos de violação a direitos econômicos e sociais", ${ }^{42}$ com objetivo de cumprir as promessas presentes nestas Constituições em face de realidades "marcadas por violações massivas a direitos e desigualdades inaceitáveis". 43

A inovação institucional proposta pelos constitucionalismos emergentes pode ser atestada pelo interesse demonstrado pela doutrina norte-americana e europeia acerca desta temática. Em especial a atuação da Corte Constitucional da Colômbia e da Corte Constitucional SulAfricana foram objeto de estudo diversos autores inseridos no "Norte global". ${ }^{4}$

É o que César Rodríguez Garavito e Diana Rodriguez definem como "giro paradoxal da história social e jurídica"45: a Corte colombiana, outrora mera expectadora do direito produzido nos países de "tradição jurídica", passou a ser exportadora de uma jurisprudência institucionalmente inovadora, que assegurasse o cumprimento de decisões ambiciosas na tutela de direitos - o que é extensível, em maior ou menor grau, a todas as experiências estruturantes do Sul global.

A Corte Constitucional da Colômbia, inclusive, é usualmente apontada como principal exemplo de decisões estruturantes no âmbito de direitos socioeconômicos. A utilização de técnicas desta natureza se

42 RODRÍGUEZ-GARAVITO, César. Beyond the courtroom: the impact of judicial activism on socioeconomic rights in Latin America. Texas Law Review, vol. 89, 2011, p. 1671.

43 RODRÍGUEZ-GARAVITO, César. Beyond the courtroom: the impact of judicial activism on socioeconomic rights in Latin America. Texas Law Review, vol. 89, 2011, p. 1697.

${ }^{44}$ A título exemplificativo, SUNSTEIN, Cass. Social and Economic Rights? Lessons from South Africa. John M. Olin Program in Law and Economics Working Paper n. 124, 2001; LANDAU, David. The reality of social rights enforcement. Harvard International Law Journal, vol. 53, n. 1, 2012; WEAVER, Russel L. The Rise and decline of structural remedies. San Diego Law Review, vol. 41, 2004; KAPISZEWSKI, Diana. High courts and economic governance in Argentina and Brazil. Cambridge University Press, 2012;

45 RODRÍGUEZ-GARAVITO, César; RODRÍGUEZ-FRANCO, Diana. Cortes y cambio social: cómo la Corte Constitucional transformó el desplazamiento forzado en Colombia. Bogotá: Centro de Estudios de Derecho, Justicia y Sociedad, 2010, p. 10. 


\section{DECISÕES ESTRUTURANTES NA JURISDIÇÃO CONSTITUCIONAL BRASILEIRA}

deu, por exemplo, em relação à situação da Defensoria Pública no país, ${ }^{46}$ questões previdenciárias da carreira docente, ${ }^{47}$ a superlotação do sistema carcerário $^{48}$ e, no caso mais célebre, na declaração do estado de coisas inconstitucional em relação aos deslocamentos forçados decorrentes do narcotráfico. ${ }^{49}$

Da mesma forma, a Corte Constitucional Sul-africana, passou a atuar ativamente contra o legado econômico do Apartheid, ${ }^{50}$ sobretudo no que diz respeito a direitos relativos à saúde e à seguridade social, ${ }^{51}$ bem como no consagrado Government of the Republic of South Africa vs. Grootboom, em que discutiu o papel do Estado na tutela do direito à moradia.

O legado das decisões estruturantes nestes contextos não deve ser aferido tão somente a partir de seu êxito na resolução do caso concreto que as circunda. Provimentos desta complexidade tem, por consequência, efeitos também complexos e que assim devem ser apreendidos.

As decisões estruturantes poderiam ser desacreditadas a partir de argumentos tais quais o fato de a Colômbia continuar a ser o país com mais deslocados internos no mundo ${ }^{52}$ ou o fato de Irene Grootboom - o indivíduo por detrás do caso que chegou à Corte - ter morrido enquanto ainda morava em um casebre miserável..$^{53}$ Estas abordagens, ainda que não possam ser ignoradas na avaliação destes instrumentos, não encerram a discussão.

Junto dos efeitos materiais diretos (relativos à resolução do caso concreto), há efeitos simbólicos e indiretos. As decisões estruturantes, mais que outros provimentos jurisdicionais, definem o problema atacado como uma violação de direitos humanos e fundamentais, instam a

${ }^{46}$ COLÔMBIA. Corte Constitucional. Sentencia T-590/98 (1998)

${ }^{47}$ COLÔMBIA. Corte Constitucional. Sentencia SU-559/97 (1997)

${ }^{48}$ COLÔMBIA. Corte Constitucional. Sentencia T-158/08 (2008)

${ }^{49}$ COLÔMBIA. Corte Constitucional. Sentencia T-025/04 (2004)

${ }^{50}$ SUNSTEIN, Cass. Social and Economic Rights? Lessons from South Africa. John M. Olin Program in Law and Economics Working Paper n. 124, 2001, p. 05.

${ }^{51}$ LANDAU, David. The reality of social rights enforcement. Harvard International Law Journal, vol. 53, n. 1, 2012, p. 196.

${ }^{52}$ CNN EN ESPAÑOL. Colombia vuelve a ser el país con más desplazados internos del mundo. 24 de maio de 2017.

${ }^{53}$ MAIL GUARDIAN. Grootboom dies homeless and penniless. 08 de agosto de 2008. 
opinião pública contra esta violação, demonstram a gravidade do problema e mobilizam a sociedade civil acerca da questão. ${ }^{54}$

$\mathrm{O}$ que de mais relevante se pode extrair dos provimentos estruturantes no âmbito do constitucionalismo emergente é a racionalidade que fundamenta a atividade jurisdicional e os efeitos desta decorrentes. A Corte deve atuar não apenas de forma acautelatória na tutela de direitos, mas também deve promove-los. Por isso, estas decisões não devem almejar apenas a solução do caso concreto (efeitos materiais diretos), mas também efeitos indiretos e simbólicos decorrentes de litígios desta natureza.

Em síntese, os provimentos de natureza estruturante, a partir de sua recepção pelos constitucionalismos emergentes, são identificados como modo de combate à omissão estatal na proteção e promoção dos direitos assegurados por estas Constituições. Trata-se do problema deste estudo: afinal, discutir a tutela jurisdicional de direitos prestacionais inevitavelmente decorre de uma pretensa falha do Estado na tutela de destes direitos pelos mecanismos de política ordinária.

Considerando que (i) o atual modelo de tutela jurisdicional de direitos prestacionais adotado pela jurisprudência brasileira é insuficiente; e (ii) em perspectiva comparada, é possível falar na adoção dos provimentos estruturantes como remédio em face da reiterada omissão estatal, cabe analisar a viabilidade de, do ponto de vista procedimental do processo, adotar provimentos desta natureza na jurisdição constitucional brasileira.

\section{DECISÕES ESTRUTURANTES NA JURISDIÇÃO CONSTITUCIONAL BRASILEIRA: FUNDAMENTOS LEGAIS E POTENCIALIDADES}

A adoção de decisões estruturantes na jurisdição constitucional brasileira permitiria a reestruturação de institutos estatais, dando significado aos valores constitucionais, em especial a partir de sua utilização como instrumento que obsta e contínua e reiterada omissão do Estado na proteção e promoção de direitos.

54 Os efeitos para além dos materiais e diretos são identificados sobretudo por RODRÍGUEZ-GARAVITO, César. Beyond the courtroom: the impact of judicial activism on socioeconomic rights in Latin America. Texas Law Review, vol. 89, 2011. 


\section{DECISÕES ESTRUTURANTES NA JURISDIÇÃO CONSTITUCIONAL BRASILEIRA}

Como ponto de partida, são dois os princípios gerais que devem circundar toda a discussão acerca das decisões estruturantes na jurisdição constitucional brasileira: subsidiariedade e proporcionalidade. ${ }^{55}$

As decisões estruturantes são uma exceção ao regime tradicional de separação de poderes e por isso devem ser vistas de forma subsidiária. Esta subsidiariedade se dá em dois aspectos: externo e interno.

Do ponto de vista externo, busca-se provimentos desta natureza apenas quando os mecanismos políticos ordinários falharam de forma reiterada. Notadamente, quando a promoção de direitos por meio de políticas públicas oriundas do Executivo e do Legislativo não funciona ou quando se percebe a ausência de vontade política em concretiza-las.

Do ponto de vista interno à decisão, a subsidiariedade se manifesta na primazia dos mecanismos dialógicos e flexíveis de implementação da decisão em detrimento dos mais gravosos. As intervenções mais profundas nas demais esferas de poder só serão legítimas acaso precedidas de tentativas de solução mais brandas e voltadas à busca do consenso.

O segundo princípio geral é a proporcionalidade. ${ }^{56}$ Ainda que em geral não o seja, este deveria ser fator balizador de qualquer decisão, estruturante ou não, que se dê contra o Poder Público. Isto porque, ao fim e ao cabo, a execução contra a Fazenda encontra satisfação no dinheiro público, fruto da arrecadação dos contribuintes.

Estabelecer que decisões estruturantes devem ser proporcionais significa que, por mais complexo que seja o problema enfrentado, a decisão deve impor obrigação passíveis de serem cumpridas e em período de tempo suficiente. $\mathrm{O}$ Juiz deve ponderar sobre as consequências do provimento que está concedendo, sobretudo naquilo

\footnotetext{
55 Estas duas características foram extraídas do proposto em ARENHART, Sérgio Cruz. Decisões estruturais no direito processual civil brasileiro. Revista de Processo, v. 225, 2013.

56 O conceito de proporcionalidade aqui adotado é o proposto por Robert Alexy, segundo o qual (1) trata-se de máxima estruturalmente traduzida em seus três subitens (adequação, necessidade e proporcionalidade em sentido estrito); (2) nem sempre é necessária a aplicação concomitante de todos os subitens, mas estes guardam uma relação de subsidiariedade, conforme ordem anteriormente apresentada; e (3) a proporcionalidade não possui fundamento expresso em dispositivo legal, mas decorre da estrutura dos direitos fundamentais enquanto mandamentos de otimização. Cf. ALEXY, Robert. Teoria dos direitos fundamentais. São Paulo: Malheiros, 2a․ ed., 2015, p. 116.
} 
que afeta a promoção de direitos por outras medidas já existentes e igualmente dependentes do Erário.

Partindo destas noções gerais, que devem orientar toda a compreensão da temática, os itens a seguir delineiam de modo mais preciso os contornos a serem assumidos pelas decisões estruturantes. Serão abordados (i) a competência preferencial para prolação e execução destas decisões; (ii) o fundamento processual da fase de conhecimento e execução; e (iii) a noção ampliada de contraditório e representação que deve orientar este processo.

\subsection{A competência jurisdicional para prolação e execução da decisão estruturante: ampliação da cadeia decisória}

Ao propor estudo sistemático acerca daquilo que denominou medidas estruturantes, Marco Félix Jobim propôs o Supremo Tribunal Federal como local adequado para a tomada de decisões deste caráter na jurisdição constitucional brasileira. Por consequência, também caberia ao STF implementá-las. ${ }^{57}$

A razão para tanto seria a complexidade inerente a decisões desta natureza. A reestruturação de organismos sociais, dado o amplo conflito de interesses que pressupõe, demandaria a solução da controvérsia mediante controle concentrado de constitucionalidade. ${ }^{58} \mathrm{~A}$ admissão de provimentos desta natureza pela via difusa se daria a nível de exceção, e sempre de forma a tornar possível sua objetivação em decisão final do Supremo Tribunal Federal..$^{59}$

O que aqui se defende não coaduna com essa perspectiva. Propõe-se que, apesar de o STF ser um fórum possível de discussão dos processos estruturantes, não é único, nem sequer o preferencial.

É evidente que a maioria, se não a totalidade, das decisões estruturantes serão impugnadas via recurso extraordinário e chegarão ao STF. Primeiro, porque o Estado é recorrente contumaz e o maior cliente

\footnotetext{
57 JOBIM, Marco Félix. Medidas estruturantes: da Suprema Corte estadunidense ao Supremo Tribunal Federal. Porto Alegre: Livraria do Advogado, 2013, p. 165.

5858 JOBIM, Marco Félix. Medidas estruturantes: da Suprema Corte estadunidense ao Supremo Tribunal Federal. Porto Alegre: Livraria do Advogado, 2013, p. 165-168.

${ }^{59}$ Faz-se referência à objetivação do controle de constitucionalidade difuso por meio de instrumentos inerentes a este no âmbito do Supremo Tribunal Federal, quais sejam, a afetação de recurso extraordinário pelo regime de repercussão geral e a aprovação de súmulas vinculantes.
} 


\section{DECISÕES ESTRUTURANTES NA JURISDIÇÃO CONSTITUCIONAL BRASILEIRA}

do STF pela via difusa. ${ }^{60}$ Segundo, porque provimentos de caráter estruturante trazem ínsitos questões relevantes do ponto de vista econômico, político, social ou jurídico que ultrapassem os interesses subjetivos do processo ${ }^{61}$ e, portanto, cumprem o requisito de repercussão geral para conhecimento de recurso extraordinário.

Apesar desta aparente inevitabilidade de apreciação da questão pelo Supremo Tribunal Federal, esta se dará eminentemente pela via recursal. O que se defende é que o controle de constitucionalidade estrutural não se dê originariamente no STF, mas, preferencialmente nos graus ordinários de jurisdição.

A primeira razão para que se sustente esta preferência é a longa instrução processual à qual os processos estruturantes devem se submeter. Conforme se demonstrará, a legitimidade da decisão estruturante depende da ampla participação social no processo a partir de uma noção substancial de contraditório, própria dos processos coletivos. Isto se daria de modo dificultado do STF.

$\mathrm{Na}$ qualidade de Corte de Vértice, ${ }^{62}$ o STF não possui prática ou estrutura para lidar com instrução processual que vá além do usualmente praticado no controle concentrado de constitucionalidade - o que, no mais das vezes, se resume a algumas sustentações orais e, quando muito, a convocação de audiências públicas.

O segundo fator a ser considerado diz respeito ao volume de trabalho enfrentado pelo STF. Decisões estruturantes pressupõem processos complexos e, consequentemente, custosos, do ponto de vista dos recursos humanos e financeiros do Judiciário. Seria contraproducente submeter ao STF, que já enfrenta vertiginoso acúmulo de processos, pedidos desta natureza.

Diante destas circunstâncias, pleitos que pretendam provimentos de caráter estruturantes devem, preferencialmente, ser apresentados perante os Juízos de $1^{\mathfrak{o}}$ grau, no âmbito da Justiça Estadual ou Federal. A definição

${ }^{60}$ FALCÃO, Joaquim et al. II Relatório Supremo em números: o Supremo e a Federação. Rio de Janeiro: Escola de Direito do Rio de Janeiro da Fundação Getúlio Vargas, 2013, p. 60 .

${ }^{61}$ Trata-se da definição de repercussão geral atribuída pelo art. 1.035, § 1ํㅡㄹ do Código de Processo Civil.

62 MITIDIERO, Daniel. Cortes Superiores e Cortes Supremas: do controle à interpretação, da jurisprudência ao precedente. São Paulo: Revista dos Tribunais, $2^{\underline{a}}$ ed., 2014. 
do Juízo competente, por óbvio, deve considerar a natureza do objeto litigado e a responsabilização estatal que recai sobre este.

Sendo estas decisões objeto de recurso, os Tribunais Estaduais e Regionais Federais continuam fóruns de discussão mais adequados que o STF. Enquanto última instância legitimada a fazer juízo de valor sobre as provas dos autos no procedimento ordinário, as Cortes de $2^{\circ}$ Grau possuem muito mais familiaridade com a instrução probatória que aqui se coloca como condição necessária.

A complexidade inerente aos processos estruturantes não infere na impossibilidade de apreciação destes pela jurisdição ordinária. Ao contrário, do ponto de vista pragmático, é preferível que o objeto destas demandas seja previamente delimitado de acordo com a competência territorial.

Não se nega, por exemplo, que a ausência de acesso ao saneamento básico é um problema, em maior ou menor grau, verificável em todo o país. ${ }^{63}$ Ainda assim, é preferível que os processos estruturais com este objeto sejam delimitados em Municípios e Estados, ainda que com a indicação da União no polo passivo, em lugar da proposição de uma única ação exageradamente ampla no STF.

Em determinados casos, a delimitação do objeto do litígio inferirá, necessariamente, na competência do STF. Isto pode se dar tanto pela impossibilidade de delimitação do pleito - por exemplo, a ADPF 347, em que o pedido referente à realização de audiências de custódia deveria vincular todas as esferas de jurisdição, o que só poderia ocorrer mediante decisão do STF -, como em razão de expressa previsão de competência do STF - por exemplo, pleitos que envolvam a disputa entre Estados e que serão submetidos originariamente ao Supremo (art. 102, I, ' $\mathrm{f}$ ' da Constituição). Exatamente por isso, o que se estabeleceu foi a preferência aos graus ordinários de jurisdição, e não a limitação dos provimentos de caráter estruturante a estes.

De toda forma, mesmo nos casos em que a competência para conhecimento originário da ação seja do STF, continua a se defender que as decisões estruturantes não devem se encerrar nesta Corte. Ainda que a prolação de decisão se dê no âmbito do STF, a competência para execução da mesma deve ser declinada aos Tribunais ordinários ou Juízos de $1^{\circ}$ grau, a depender de análise do caso concreto.

Trata-se de uma ampliação da cadeia decisória no âmbito da tutela executiva que Sérgio Cruz Arenhart denomina "provimentos em

63 BARCELLOS, Ana Paula de. Sanitation rights, public law litigation and inequality: a case study from Brazil. Harvard Health and Human Rights Journal, n. 2, vol. 16, 2014. 


\section{DECISÕES ESTRUTURANTES NA JURISDIÇÃO CONSTITUCIONAL BRASILEIRA}

cascata" ${ }^{64}$ Este entendimento é compartilhado por Emilio Peluso Meyer, que, em uma análise crítica acerca do estado de coisas inconstitucional na jurisdição brasileira, afirma que "mais adequado seria que essa fiscalização [da implementação da decisão] fosse feita de modo difuso e que a coordenação dos trabalhos não recaísse sobre o STF, aumentando mais uma vez suas competências" ${ }^{\prime 65}$

Adotar provimentos em cascata significa dizer que o processo decisório dos processos estruturantes se prolonga no tempo. Há, em geral, uma primeira decisão, que se limitará a criar "o núcleo da posição jurisdicional sobre o problema", 66 de forma genérica, abrangente e, no mais das vezes, com cunho principiológico.

A esta primeira decisão se seguem outras diversas decisões mais específicas, nas quais se busca de modo mais direto a implementação da tutela pretendida. Constitui-se, assim, uma "ampla cadeia de decisões, que implicarão em avanços e retrocessos no âmbito de proteção inicialmente afirmado, de forma a adequar, da melhor forma viável, a tutela judicial".${ }^{67}$

Nos termos propostos por Owen Fiss, esta ampliação da cadeia decisória implica dizer que "a execução de uma decisão estruturante tem um começo, talvez um meio, porém não tem fim - ou quase não tem fim". 68

Esta ampla cadeia decisória pode se prolongar significativamente no tempo. ${ }^{69}$ É por isso que se propõe que, mesmo nos casos em que a decisão inicial seja proferida pelo STF, a execução seja declinada aos Juízos ordinários competentes para tanto.

${ }^{64}$ ARENHART, Sérgio Cruz. Decisões estruturais no direito processual civil brasileiro. Revista de Processo, v. 225, 2013, p. 392.

${ }^{65}$ MEYER, Emílio Peluso Neder. Decisão e jurisdição constitucional: críticas às sentenças intermediárias, técnicas e efeitos do controle de constitucionalidade em perspectiva comparada. Rio de Janeiro: Lumen Juris, 2017, p. 210.

${ }^{66}$ ARENHART, Sérgio Cruz. Decisões estruturais no direito processual civil brasileiro.

Revista de Processo, v. 225, 2013, p. 392.

${ }^{67}$ ARENHART, Sérgio Cruz. Decisões estruturais no direito processual civil brasileiro.

Revista de Processo, v. 225, 2013, p. 392

${ }^{68}$ The forms of justice. Harvard Law Review, vol. 93, n. 1, 1979., p. 42.

${ }^{69}$ VIOLIN, Jordão. Protagonismo judiciário e processo coletivo estrutural: o controle jurisdicional de decisões política. Salvador: JusPodvm, 2013, p. 229. 


\subsection{A permeabilidade da demanda e a atipicidade das medidas executivas}

A lógica individual do processo civil tradicional permite que o legitimado a propor a ação - o qual, em uma perspectiva individual, é o titular do direito material - disponha de parcela de seu direito. Por isso, o Juiz deve julgar estritamente de acordo com o que foi pleiteado, a despeito de o pedido abarcar ou não a totalidade do direito material discutido. Estas noções se consubstanciam no princípio da demanda $a^{70} \mathrm{e}$ no princípio da adstrição. ${ }^{71} \mathrm{~A}$ atuação jurisdicional é, desde seu início, limitada ao teor da petição inicial, o que restringe as possibilidades de atuação do Juiz.

Estas noções acabam sendo indevidamente reproduzidas nas ações coletivas. Sérgio Cruz Arenhart identifica a plena incidência do princípio da demanda ao processo coletivo, o que pode gerar o perverso efeito de que o pleito levado a Juízo contrarie a vontade da coletividade ou o interesse do grupo representado. ${ }^{72}$

As decisões estruturantes não podem reproduzir este equívoco. Um pedido mal formulado ou a atuação irregular do legitimado ativo da ação coletiva não pode gerar uma decisão desfavorável a toda uma coletividade titular do direito em questão.

As demandas de potencial estruturante devem ser vistas de maneira permeável. Com a mitigação das ideias de demanda e adstrição, o Juiz "diante das evidências da insuficiência ou inadequação da tutela pretendida pelo autor na petição inicial, deve extrapolar os limites do pedido". ${ }^{73}$

A possibilidade de mitigar os princípios da demanda e da adstrição decorre do próprio direito à tutela jurisdicional adequada, o qual pressupõe a primazia do mérito em relação ao instrumento. ${ }^{74} \mathrm{O}$ adequado

${ }^{70} \mathrm{O}$ processo começa por iniciativa da parte e se desenvolve por impulso oficial, salvo as exceções previstas em lei (CPC/15, art. $2^{\circ}$.).

${ }^{71} \mathrm{O}$ pedido deve ser certo $(\mathrm{CPC} / 15$, art. 322).

72 ARENHART. Sérgio Cruz. Processo multipolar, participação e representação de interesses concorrentes. In: ARENHART, Sérgio Cruz; JOBIM, Marco Félix (org.). Processos estruturais. Salvador: JusPodivm, 2017, p. 427

${ }^{73}$ ARENHART, Sergio Cruz. Processos estruturais no direito brasileiro: reflexões a partir do caso da ACP do carvão. Revista de Processo Comparado: RPC, v. 1, n. 2, p. 211229, jul./dez. 2015, p. 217.

${ }^{74} \mathrm{CPC} / \mathbf{1 5}$. Art. $\mathbf{4}^{\circ}$. As partes têm o direito de obter em prazo razoável a solução integral do mérito, incluída a atividade satisfativa. 


\section{DECISÕES ESTRUTURANTES NA JURISDIÇÃO CONSTITUCIONAL BRASILEIRA}

funcionamento da jurisdição reside "na apropriada identificação das necessidades substanciais do que deve ser tutelado em juízo" e na prioridade deste direito material em relação às formalidades do processo. ${ }^{75}$

Esta permeabilidade do processo estruturante em fase de conhecimento deve ser estendida à fase de execução. Mesmo porque o já citado art. $4^{\circ}$ do CPC, ao estabelecer a primazia do mérito, inclui neste bojo a atividade satisfativa.

Defender a permeabilidade das medidas executivas quando da implementação de decisões estruturantes é, ao menos do ponto de vista dogmático, mais simples. Enquanto a flexibilização do princípio da demanda e da adstrição não encontra respaldo geral em texto de lei, decorrendo de uma interpretação sistemática do direito fundamental à tutela jurisdicional adequada, a atipicidade das medidas executivas é a regra do Código de Processo Civil.

Fredie Didier Jr. e Hermes Zaneti Jr. propõem que a base normativa da execução das decisões estruturantes decorre da combinação dos artigos 139, IV,$^{76}$ e 536, § 10 77 do CPC. Nestes estão inscritas as "cláusulas gerais de execução, das quais decorre para o órgão julgador o poder de promover a execução de suas decisões por medidas atípicas". ${ }^{78}$

A utilização de medidas executivas atípicas, ainda que fundamento do processo de implementação de decisões estruturantes, deve ser vista com cautela. Jordão Violin manifesta preocupação com a falta de familiaridade do Poder Judiciário com medidas coercitivas atípicas, que,

\footnotetext{
${ }^{75}$ MARINONI, Luiz Guilherme; ARENHART, Sérgio Cruz; MITIDIERO, Daniel. O novo processo civil. $2^{\underline{a}}$ ed., São Paulo: Revista dos Tribunais, 2016, p. 185.

${ }_{76} \mathrm{O}$ juiz dirigirá o processo conforme as disposições deste Código, incumbindo-lhe: IV - determinar todas as medidas indutivas, coercitivas, mandamentais ou sub-rogatórias necessárias para assegurar o cumprimento de ordem judicial, inclusive nas ações que tenham por objeto prestação pecuniária (CPC/15, art. 139.).

${ }_{77}$ Para atender ao disposto no caput, o juiz poderá determinar, entre outras medidas, a imposição de multa, a busca e apreensão, a remoção de pessoas e coisas, o desfazimento de obras e o impedimento de atividade nociva, podendo, caso necessário, requisitar o auxílio de força policial (CPC/15, art. 536, § 1º).

${ }^{78}$ DIDIER JR., Fredie; ZANETI JR., Hermes; OLIVEIRA, Rafael Alexandria. Notas sobre as decisões estruturantes. In: ARENHART, Sérgio Cruz; JOBIM, Marco Félix (org.). Processos estruturais. Salvador: JusPodivm, 2017, p. 363.
} 
“se já são um problema no âmbito privado, podem tornar-se verdadeiro pesadelo em matéria de políticas públicas". ${ }^{79}$

No âmbito dos processos estruturantes, as medidas de implementação da decisão podem ser classificadas em dois grandes grupos: as medidas dialógicas e as medidas coercitivas. As medidas dialógicas são aquelas em que as entidades públicas condenadas são chamadas a fazer parte, de modo ativo, da implementação da decisão.

É exemplo de medida dialógica a convocação do próprio órgão estatal para elaboração do plano de implementação da decisão e, a partir do monitoramento por parte da jurisdição fiscalizatória, a manutenção deste diálogo para a flexibilização e adequação das medidas a serem tomadas.

Esses são os meios de execução menos invasivos e os quais tem primazia na implementação da decisão. Não se verificando efeitos relevantes a partir destas medidas dialógicas, passa-se, subsidiariamente, às medidas coercitivas.

A imposição de medidas coercitivas nos processos estruturais deve levar em consideração um parâmetro básico de qualquer tutela executiva, qual seja, a concretização da atividade satisfativa de modo a causar o menor gravame possível ao réu. ${ }^{80}$ Isto é especialmente pertinente quando o réu é o Estado, considerando que a condenação recairá sobre o orçamento público, e não sobre bens privados.

No âmbito dos provimentos estruturantes, uma medida coercitiva possui especial relevância: o bloqueio de verbas públicas. Não se está aqui defendendo o uso contínuo e reiterado do bloqueio de verbas públicas, medida bastante gravosa e a qual intervém de forma direta na esfera de atuação dos demais poderes. Conforme já mencionado, a proporcionalidade é um princípio geral das decisões estruturantes e deve ser plenamente observada na sua implementação.

O que aqui se defende é, em verdade, mais restritivo do que prática atualmente observada na jurisprudência brasileira. O STJ, por exemplo, reconheceu em sede de recurso repetitivo - portanto, vinculante aos graus ordinários de jurisdição-, que é possível sequestrar verbas públicas em caso de descumprimento do Estado em face de decisão que deferiu o fornecimento de medicamentos. ${ }^{81}$ Com a decisão do STJ, é bastante

79 VIOLIN, Jordão. Protagonismo judiciário e processo coletivo estrutural: o controle jurisdicional de decisões política. Salvador: JusPodvm, 2013, p. 229.

${ }^{80}$ Quando por vários meios o exequente puder promover a execução, o juiz mandará que se faça pelo modo menos gravoso para o executado (CPC/15, art. 805).

81 BRASIL. Superior Tribunal de Justiça. Recurso especial 1.069.810/RS. Rel. Min. Napoleão Nunes Maia Filho, 1aㅗ Seção, julgado em 23.10.2013. 


\section{DECISÕES ESTRUTURANTES NA JURISDIÇÃO CONSTITUCIONAL BRASILEIRA}

comum - para não dizer corriqueiro - o bloqueio de verbas públicas para $\mathrm{o}$ atendimento de direitos de cunho prestacional, ${ }^{82}$ quase que unicamente no âmbito individual-privado.

O que aqui se defende é a limitação deste mecanismo aos processos nos quais a tutela jurisdicional pretendida estrutural. Trata-se da transferência de verba pública para satisfação de direito eminentemente individual e privado. Esta situação se altera no âmbito do processo estrutural. Neste caso, o bloqueio de verbas públicas se dará em prol da coletividade, e não de indivíduo único e específico.

\subsection{A redefinição do contraditório e a representação adequada no processo estruturante}

O processo estruturante precisa desenvolver uma noção própria de direito ao contraditório. A compreensão deste como direito de influenciar o convencimento do Juiz, quando transposta a um processo de natureza coletiva, não pode se limitar à atuação do substituto processual. É necessária "a participação de toda coletividade, na medida em que a política pública também se destina a toda ela". ${ }^{83}$

O processo estruturante foge à lógica individual. Trata-se de demanda na qual não há mera contraposição entre autor e réu, mas vários interesses contrapostos, o que gera um processo multipolar. ${ }^{84}$ Este caráter amplo e consequências pouco calculáveis de antemão dos provimentos estruturantes inferiu em críticas das mais diversas ordens na doutrina norte-americana.

Para Gerald Rosenberg, os Tribunais não teriam meios institucionais que os permitiriam implementar e monitorar as decisões acerca de temáticas complexas, ${ }^{85}$ no que se inserem os provimentos decorrentes de

${ }^{82}$ A título exemplificativo: TJPR. Apelação cível no 1590003-9. Rel.: Desembargadora Maria Aparecida Blanco de Lima, 44 Câmara Cível, julgado em 04.04.2017; TRF4. Agravo de instrumento $\mathbf{n}^{\mathrm{0}}$ 5015005-37.2014.404.0000. Rel.: Desembargador Federal Fernando Quadros da Silva, 3ํㅡㄹ Turma, julgado em 27 de agosto de 2014.

${ }^{83}$ ARENHART, Sérgio Cruz. Processos estruturais no direito brasileiro: reflexões a partir do caso da ACP do carvão. Revista de Processo Comparado: RPC, v. 1, n. 2, p. 211229, ACP, p. 219.

${ }^{84}$ YEAZELL, Stephen C. The ordinary and the extraordinary in institucional litigation. Harvard Law Review, vol. 93, n. 3, 1980.

${ }^{85}$ ROSENBERG, Gerald N. The hollow hope: can Courts bring about social change? 2 ed., Chicago: University of Chicago Press, 2008. 
litígios de interesse público. Isto corrobora o que Lon Fuller chamou de "problema policêntrico": o fato de o Juiz estar adstrito ao que é levado à Corte pelas partes faria com que não fosse desejável o debate de questões de alta complexidade e repercussão para além das partes em litígio. ${ }^{86}$

Em sentido oposto, Owen Fiss entende que o Poder Judiciário seria fórum adequado para discussões complexas e de interesse público em razão de algumas das características próprias da atividade jurisdicional. Em primeiro, o Juiz não pode escolher quais questões serão a ele submetidas e, da mesma forma, não possui o total controle sobre quem será ouvido no processo. Nesta medida, o exercício do contraditório tende a fornecer a ele todos os dados necessários, mediante profundo debate pelos interessados. ${ }^{87} \mathrm{~A}$ representação adequada em processos estruturantes mitigaria, por meio do contraditório, sanaria este "problema policêntrico" e conferiria legitimidade às decisões estruturantes.

A concretização desta perspectiva substancial de contraditório é exemplificada por Sérgio Cruz Arenhart por meio de instrumentos tais quais a convocação de audiências públicas, os amici curiae e a participação de técnicos especialistas no tema objeto da demanda. ${ }^{88}$ Estes instrumentos materializam o abandono da tradicional posição de superioridade interpretativa do Poder Judiciário para dar lugar a um diálogo aberto com os demais ramos políticos e com o povo. ${ }^{89}$

Da mesma forma, a admissão de amicus curiae e designação de audiências públicas rompe com a noção tradicional da intervenção de terceiros no processo, ${ }^{90}$ notadamente pensada para os conflitos individuais e privados. Este é, inclusive, um dos fatores pelos quais não se pode falar, abstratamente, em uma superioridade do controle concentrado de constitucionalidade em relação ao difuso. O que outrora

\footnotetext{
${ }^{86}$ FULLER, Lon. The Forms and Limits of Adjudication, Harvard Law Review, v. 92, n. $02,1976$.

${ }^{87}$ FISS, Owen. To make the Constitution a living truth: four lectures on the structural injunction. In: ARENHART, Sérgio Cruz; JOBIM, Marco Félix (org.). Processos estruturais. Salvador: JusPodivm, 2017.

88 ARENHART, Sérgio Cruz. Decisões estruturais no direito processual civil brasileiro. Revista de Processo, v. 225, 2013, p. 220.

89 GODOY, Miguel Gualano de. Devolver a constituição ao povo: crítica à supremacia judicial e diálogos institucionais. Belo Horizonte: Fórum, 2017, p. 175.

90 DIDIER JR., Fredie; ZANETI JR., Hermes; OLIVEIRA, Rafael Alexandria. Notas sobre as decisões estruturantes. In: ARENHART, Sérgio Cruz; JOBIM, Marco Félix (org.). Processos estruturais. Salvador: JusPodivm, 2017, p. 363.
} 


\section{DECISÕES ESTRUTURANTES NA JURISDIÇÃO CONSTITUCIONAL BRASILEIRA}

eram mecanismos próprios das ações do controle abstrato foram, sobretudo a partir do Código de Processo Civil de 2015, ampliados para todas as esferas processuais.

Isto pode ser resumido na noção de que a legitimidade processual das decisões estruturantes é proporcional à qualidade do debate que a antecedeu. ${ }^{91}$ Mesmo porque, ao contrário do processo individual, o conflito estrutural não diz respeito tão somente a dois polos de interesses contrapostos. A racionalidade destes conflitos é diversa: trata-se de um processo multipolar nos quais, superando a lógica bipolarizada, são formados diversos núcleos de interesses, muitas vezes antagônicos, acerca do objeto do litígio. ${ }^{92}$

Mais do que a mera defesa de uma posição unilateral, o processo estrutural deve se tornar "palco de negociações e de debates prospectivos, procurando uma regulação razoável" ${ }^{\prime 93}$ para a problemática que se busca sanar. Estas concepções podem ser resumidas naquilo que Edilson Vitorelli descreve como "modelo de processo town meeting". ${ }^{94} \mathrm{O}$ Juiz toma a direção do processo de modo a fomentar o diálogo passível de se estender à parcela da sociedade impactada e aos órgãos administrativos e/ou legislativas cuja responsabilização se objetiva..$^{95}$

Observar o processo estrutural por meio deste filtro do contraditório amplo também infere no controle da representação processual adequada. O direito brasileiro, no âmbito da regulação do processo coletivo, optou por dar ampla legitimidade a instituições muitas vezes afastadas da controvérsia - como o Ministério Público, a Defensoria Pública e os entes

91 VIOLIN, Jordão. Protagonismo judiciário e processo coletivo estrutural: o controle jurisdicional de decisões política. Salvador: JusPodvm, 2013, p. 146.

92 ARENHART. Sérgio Cruz. Processo multipolar, participação e representação de interesses concorrentes. In: ARENHART, Sérgio Cruz; JOBIM, Marco Félix (org.). Processos estruturais. Salvador: JusPodivm, 2017, p. 424.

93 OSNA, Gustavo. Nem "tudo", nem "nada" - decisões estruturais e efeitos jurisdicionais complexos. In: ARENHART, Sérgio Cruz; JOBIM, Marco Félix (org.). Processos estruturais. Salvador: JusPodivm, 2017, p. 184.

${ }^{94}$ VITORELLI, Edilson. O devido processo legal coletivo: dos direitos aos litígios coletivos. São Paulo: Revista dos Tribunais, 2016.

${ }^{95}$ VITORELLI, Edilson. O devido processo legal coletivo: dos direitos aos litígios coletivos. São Paulo: Revista dos Tribunais, 2016. 
federativos. Isto pode gerar o que Sérgio Cruz Arenhart define como um "processo 'descolado' da realidade". ${ }^{96}$

Não se está sugerindo a reforma da legislação para exclusão de qualquer um dos legitimados no âmbito das ações coletivas. $\mathrm{O}$ que se quer dizer é que, especialmente nos casos em que forem estes os autores das ações coletivas, torna-se imprescindível possibilitar a ampla participação dos interessados na demanda.

Em processos nos quais se busca conciliar uma ampla gama de interesses distintos, o Juiz precisa ter acesso às mais diversas compreensões da problemática impugnada. Apenas se respeitados estes parâmetros é que a decisão encontrará legitimação do ponto de vista democrático.

\section{CONCLUSÕES}

Com o objetivo de proteger e promover direitos humanos, a jurisdição constitucional conta com uma ampla "caixa de ferramentas", ${ }^{97}$ que pode (e deve) ter seus instrumentos combinados para além das construções tradicionais. A proposta deste estudo foi estabelecer as decisões estruturantes como instrumento de tutela jurisdicional adequado de direitos prestacionais. Partiu-se de um conceito segundo o qual as decisões estruturantes devem ser entendidas como decisões judiciais por meio das quais se busca a reestruturação de determinada organização social ou política pública, com o objetivo de concretizar direitos ou interesses socialmente relevantes.

$\mathrm{Na}$ tentativa de fixar critérios a balizar esta atuação jurisdicional, verificou-se que, sob o viés de direito material - ou seja, um critério que diz respeito a quais direitos devem ser protegidos pela via judicial e em que intensidade -, o parâmetro usualmente apontado é o do mínimo existencial. Entretanto, este é um critério insuficiente, pois (i) o conteúdo

96 ARENHART. Sérgio Cruz. Processo multipolar, participação e representação de interesses concorrentes. In: ARENHART, Sérgio Cruz; JOBIM, Marco Félix (org.). Processos estruturais. Salvador: JusPodivm, 2017, p. 426.

97 Leonardo Coelho Ribeiro propõe que o direito administrativo deve ser visto como "caixa de ferramentas". Por meio desta metáfora, afirma-se que, com a congregação de diferentes instrumentos, com capacidades diversas, é possível orientar a seleção, combinação e manejo destas ferramentas no intento de cumprir o objetivo pretendido. Cf. RIBEIRO, Leonardo Coelho. O direito administrativo como "caixa de ferramentas": uma nova abordagem da ação pública. São Paulo: Saraiva, 2016. 


\section{DECISÕES ESTRUTURANTES NA JURISDIÇÃO CONSTITUCIONAL BRASILEIRA}

do mínimo existencial varia conforme o caso concreto; e (ii) a tutela jurisdicional de direitos prestacionais não se limita ao mínimo existencial.

Diante da inadequação dos critérios de ordem material, passou-se a propor critérios de ordem processual, no que se inserem as decisões estruturantes. Nos termos propostos neste trabalho, as decisões estruturantes conformam provimentos jurisdicionais de natureza pública e coletiva em detrimento de demandas individuais e privadas

A origem da concepção de decisões estruturantes no julgamento do caso Brown vs. Board of Education pela Suprema Corte dos Estados Unidos, foi ressignificada com a recepção de provimentos desta natureza pelos constitucionalismos emergentes e sua nova conformação. Considerando a inserção da jurisdição constitucional brasileira neste constitucionalismo emergente, intentou-se a abordagem pragmática das decisões estruturantes na jurisdição constitucional brasileira.

No intento de operacionaliza-las, partiu-se de dois pressupostos gerais, os quais devem balizar toda a atividade jurisdicional no âmbito dos processos desta natureza: a subsidiariedade e a proporcionalidade. A subsidiariedade é externa e interna. Externamente, significa dizer que os provimentos de caráter estrutural devem ser utilizados apenas quando os instrumentos ordinários de política e de jurisdição não demonstrem sucesso na resolução da questão constitucional controversa. Internamente, significa dizer que os meios mais gravosos de implementação da decisão são sempre subsidiários em relação às medidas dialógicas.

A proporcionalidade impõe ao Juiz a consideração da adequação e das possibilidades de cumprimento da decisão proferida. Especialmente quando a condenação recai sobre o orçamento público, a decisão deve considerar a potencialidade de o provimento em questão prejudicar a promoção e proteção de direitos que estão sendo levadas a cabo por outras medidas, igualmente dependentes de recursos do Estado.

A competência da prolação e execução das decisões estruturantes foi fixada preferencialmente nos graus ordinários de jurisdição. Em que pese o STF seja fórum possível de discussão de provimentos desta natureza, não é o preferencial.

As decisões estruturantes impõem, necessariamente, uma ampla cadeia decisória, que se prolonga no tempo. Pela mesma razão, o Juízo deve manter jurisdição fiscalizadora, para prolação de decisões intermediárias e verificação do cumprimento da decisão.

Os processos estruturantes impõem a mitigação das noções de demanda e adstrição em seu viés clássico do processo civil. As medidas executivas para implementação destas decisões são atípicas, mas devem 
observar, nos termos anteriormente propostos, os critérios de proporcionalidade e subsidiariedade. O processo estruturante impõe uma visão renovada e substancial de contraditório e da representação no processo coletivo. A participação da sociedade e do Estado deve ser ampla, de modo que a legitimidade da decisão é intimamente ligada à qualidade do debate que a precedeu.

Em suma, este artigo objetiva, por meio do proposto, apresentar singela contribuição a uma tentativa de construir uma jurisdição constitucional razoável, protetiva e promotora de direitos humanos.

\section{REFERÊNCIAS}

ALEXY, Robert. Teoria dos direitos fundamentais. São Paulo:

Malheiros, 2 $2^{\underline{a}}$. ed., 2015.

ARENHART, Sérgio Cruz. Decisões estruturais no direito processual civil brasileiro. Revista de Processo, v. 225, 2013.

Processos estruturais no direito brasileiro: reflexões a partir do caso da ACP do carvão. Revista de Processo Comparado: RPC, v. 1, n. 2, p. 211-229, jul./dez. 2015.

Processo multipolar, participação e representação de interesses concorrentes. In: ARENHART, Sérgio Cruz; JOBIM, Marco Félix (org.). Processos estruturais. Salvador: JusPodivm, 2017.

BARCELLOS, Ana Paula de. A eficácia jurídica dos princípios constitucionais: o princípio da dignidade da pessoa humana. 3. ed. Rio de Janeiro: Renovar, 2011.

Sanitation rights, public law litigation and inequality: a case study from Brazil. Harvard Health and Human Rights Journal, n. 2, vol. 16, 2014.

BARROSO, Luís Roberto. Da falta de efetividade à judicialização excessiva: direito à saúde, fornecimento gratuito de medicamentos e 


\section{DECISÕES ESTRUTURANTES NA JURISDIÇÃO CONSTITUCIONAL}

BRASILEIRA

parâmetros para a atuação judicial. In: SARMENTO, Daniel; SOUZA NETO, Claudio Pereira, (orgs.). Direitos Sociais: Fundamentos, Judicialização e Direitos Sociais em Espécie. Rio de Janeiro: Lumen Juris, 2008.

BRASIL. Superior Tribunal de Justiça. Recurso especial 1.069.810/RS. Rel. Min. Napoleão Nunes Maia Filho, 1ª Seção, julgado em 23.10.2013. . Tribunal de Justiça do Estado do Paraná. Apelação cível no 1590003-9. Rel.: Desembargadora Maria Aparecida Blanco de Lima, $4^{\text {a }}$ Câmara Cível, julgado em 04.04.2017 . Tribunal Regional Federal da $4^{a}$ Região. Agravo de instrumento no 5015005-37.2014.404.0000. Rel.: Desembargador Federal Fernando Quadros da Silva, 3ํㅡㄹ Turma, julgado em 27 de agosto de 2014.

CANOTILHO, J. J. Gomes. Direito constitucional e teoria da constituição. 7. ed. Coimbra: Almedina, 2003.

CHAYES, Abram. The role of the judge in public law litigation. Harvard Law Review, vol. 89, n. 7, 1976.

CNJ. Relatório anual do Poder Ju diciário - 2016, p. 104. Disponível em $<$ http://www.cnj.jus.br/files/conteudo/arquivo/2016/10/b8f46be3dbbff344 931a933579915488.pdf>. Acesso em: janeiro de 2018.

CNN EN ESPAÑOL. Colombia vuelve a ser el país con más desplazados internos del mundo. 24 de maio de 2017. Disponível em <goo.gl/R5uxfY>. Acesso em: 17 out. de 2017.

COLÔMBIA. Corte Constitucional. Sentencia T-158/08 (2008).

Disponível em: 
$<$ http://www.corteconstitucional.gov.co/relatoria/2008/T-158-08.htm>. Acesso em: 17 out. 2017.

Sentencia SU-559/97 (1997). Disponível em:

$<$ http://www.corteconstitucional.gov.co/relatoria/1997/SU559-97.htm $>$. Acesso em: 17 out. 2017.

Sentencia T-025/04 (2004). Disponível em:

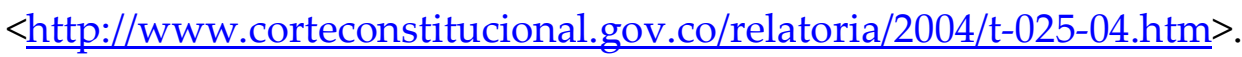
Acesso em: 17 out. 2017.

Sentencia T-590/98 (1998). Disponível em:

$<$ http://www.corteconstitucional.gov.co/relatoria/1998/T-590-98.htm>. Acesso em: 17 out. 2017.

DIDIER JR., Fredie; ZANETI JR., Hermes; OLIVEIRA, Rafael Alexandria. Notas sobre as decisões estruturantes. In: ARENHART, Sérgio Cruz; JOBIM, Marco Félix (org.). Processos estruturais. Salvador: JusPodivm, 2017.

FACHIN, Melina Girardi; GONÇALVES, Marcos Alberto Rocha. De fora, de cima e de baixa - todos os sentidos da dignidade no discurso dos direitos. Revista brasileira de direitos e garantias fundamentais. Curitiba, v. 2, n. 2, p. 78 -94, jul./dez. 2016.

FALCÃO, Joaquim et al. II Relatório Supremo em números: o Supremo e a Federação. Rio de Janeiro: Escola de Direito do Rio de Janeiro da Fundação Getúlio Vargas, 2013, p. 60.

FISS, Owen. Models of adjudication. Caderno Direito GV, v. 1, n. 8, 2005.

.The forms of justice. Harvard Law Review, vol. 93, n. 1, 1979. 


\section{DECISÕES ESTRUTURANTES NA JURISDIÇÃO CONSTITUCIONAL}

BRASILEIRA

. To make the Constitution a living truth: four lectures on the structural injunction. In: ARENHART, Sérgio Cruz; JOBIM, Marco Félix (org.). Processos estruturais. Salvador: JusPodivm, 2017.

. Two models of adjudication. In: DIDIER JR., Fredie; JORDÃO, Eduardo Ferreira. Teoria geral do processo. Salvador: JusPodivm, 2007.

Um novo processo civil: estudos norte-americanos sobre jurisdição, constituição e sociedade. São Paulo: Revista dos Tribunais, 2004.

FOLHA DE SÃO PAULO. Doentes graves ganham na Justiça, mas remédios caros travam no SUS. 16.07.2017. Disponível em < https://goo.gl/9emkSr >. Acesso em: janeiro de 2018.

FULLER, Lon. The Forms and Limits of Adjudication, Harvard Law Review, v. 92, n. 02, 1976.

GARGARELLA, Roberto. La sala de máquinas de la Constitución. Buenos Aires: Katz, 2014.

GODOY, Miguel Gualano de. Devolver a constituição ao povo: crítica à supremacia judicial e diálogos institucionais. Belo Horizonte: Fórum, 2017.

JOBIM, Marco Félix. Medidas estruturantes: da Suprema Corte estadunidense ao Supremo Tribunal Federal. Porto Alegre: Livraria do Advogado, 2013.

KAPISZEWSKI, Diana. High courts and economic governance in Argentina and Brazil. Cambridge University Press, 2012. 
LANDAU, David. The reality of social rights enforcement. Harvard International Law Journal, vol. 53, n. 1, 2012.

MAIL GUARDIAN. Grootboom dies homeless and penniless. $08 \mathrm{de}$ agosto de 2008. Disponível <goo.gl/iop4Dy>. Acesso em: outubro de 2017.

MARINONI, Luiz Guilherme; ARENHART, Sérgio Cruz; MITIDIERO, Daniel. O novo processo civil. $2^{\underline{a}}$ ed., São Paulo: Revista dos Tribunais, 2016.

MEYER, Emílio Peluso Neder. Decisão e jurisdição constitucional: críticas às sentenças intermediárias, técnicas e efeitos do controle de constitucionalidade em perspectiva comparada. Rio de Janeiro: Lumen Juris, 2017.

MITIDIERO, Daniel. Cortes Superiores e Cortes Supremas: do controle à interpretação, da jurisprudência ao precedente. São Paulo: Revista dos Tribunais, 2ª ed., 2014.

OSNA, Gustavo. Nem "tudo", nem "nada" - decisões estruturais e efeitos jurisdicionais complexos. In: ARENHART, Sérgio Cruz; JOBIM, Marco Félix (org.). Processos estruturais. Salvador: JusPodivm, 2017.

RIBEIRO, Leonardo Coelho. O direito administrativo como "caixa de ferramentas": uma nova abordagem da ação pública. São Paulo: Saraiva, 2016.

RODRÍGUEZ-GARAVITO, César. Beyond the courtroom: the impact of judicial activism on socioeconomic rights in Latin America. Texas Law Review, vol. 89, 2011.

.RODRÍGUEZ-FRANCO, Diana. Cortes y cambio social: cómo la

Corte Constitucional transformó el desplazamiento forzado en 


\section{DECISÕES ESTRUTURANTES NA JURISDIÇÃO CONSTITUCIONAL}

BRASILEIRA

Colombia. Bogotá: Centro de Estudios de Derecho, Justicia y Sociedad, 2010.

ROSENBERG, Gerald N. The hollow hope: can Courts bring about social change? 2 ed., Chicago: University of Chicago Press, 2008.

SARMENTO, Daniel. Dignidade da pessoa humana: conteúdo, trajetórias e metodologia. $2^{a}$ ed., Belo Horizonte: Fórum, 2016.

; SOUZA NETO, Claudio Pereira, (orgs.). Direitos sociais:

fundamentos, judicialização e direitos sociais em espécie. Rio de Janeiro: Lumen Juris, 2008.

SCHLANGER, Margo. Beyond the hero judge: institutional reform litigation as litigation. Michigan Law Review, v. 97, n. 6, 1999.

SUNSTEIN, Cass. Social and Economic Rights? Lessons from South Africa. John M. Olin Program in Law and Economics Working Paper n. 124, 2001.

ESTADOS UNIDOS DA AMÉRICA. US Supreme Court. Brown v. Board of Education of Topeka, 347 U.S. 483 (1954).

. US Supreme Court. Brown v. Board of Education of Topeka, 349 U.S. 294 (1955). . US Supreme Court. Plessy v. Ferguson, 163 U.S. 537 (1896). . US. District Court for the Eastern District of Arkansas. 309 F. Supp. 362 (E.D. Ark. 1970) February 18, 1970. 
VIOLIN, Jordão. Holt v. Sarver e a reforma do sistema prisional no Arkansas. In: ARENHART, Sérgio; JOBIM, Marco Félix (org.). Processos estruturais. Salvador: JusPodivm, 2017, p. 303.

Protagonismo judiciário e processo coletivo estrutural: o

controle jurisdicional de decisões política. Salvador: JusPodvm, 2013.

VITORELLI, Edilson. O devido processo legal coletivo: dos direitos aos litígios coletivos. São Paulo: Revista dos Tribunais, 2016.

WEAVER, Russel L. The Rise and decline of structural remedies. San Diego Law Review, vol. 41, 2004.

YEAZELL, Stephen C. The ordinary and the extraordinary in institutional litigation. Harvard Law Review, vol. 93, n. 3, 1980.

DECISÕES ESTRUTURANTES NA JURISDIÇÃO CONSTITUCIONAL BRASILEIRA: CRITÉRIOS PROCESSUAIS DA TUTELA JURISDICIONAL DE DIREITOS PRESTACIONAIS

STRUCTURAL INJUNCTIONS IN BRAZILIAN JUDICIAL REVIEW: PROCEDURAL STANDARDS FOR WELFARE RIGHTS.

Submetido em: 2018-05-29

Aprovado em: 2018-06-23 